Journal of Social Sciences 8 (1): 91-94, 2012

ISSN 1549-3652

(C) 2012 Science Publications

\title{
A Study of Relationship Marketing on Customer Satisfaction
}

\author{
Sheng Chung Lo \\ Department of Travel Management, \\ Tourism Hospitality School, Hsing Wu Institute of Technology, Taiwan
}

\begin{abstract}
Problem statement: Developing a sound knowledge on the customers' necessities and preferences and producing accordingly the companies can lower the chances of losing customers as well as remove negative attitude towards foreign attitudes towards foreign brands. Approach: The research works of different authors have been analysed for performing present a research work on this topic. The study compiles many research works already undertaken in this area. Results: Such a study has provided us a detailed explanation on the impact of relationship management in maintaining customer satisfaction. The various strategies that have been adopted by the organizations are found to be highly significant for running the organization successfully. Outcomes obtained through researches show that the application of the concept of relationship marketing in the organization helps in maintaining a healthy customer relation. The company will be enjoying a better position and be more confident with the fact that old customers have been retained. Satisfaction and Trust are the two main pillars of the organizations. Conclusion: The aim of the firms should be to lure consumers by adopting a particular kind of behaviour or attitude. This will encourage an ongoing reciprocal interaction between the customer and the product, service or business concerned parties. This method of building relation has been highlighted throughout the study in the process of buying and selling.
\end{abstract}

Key words: Relationship marketing, customer satisfaction, customer communication, organization performance, organization aimed

\section{INTRODUCTION}

Marketing is one of the key function and aggregation of processes in an organization aimed at creating and delivering values to the customers. It creates effective relationships with the customer besides successful communication on the behalf of the organization. This proves beneficial to the firms and stakeholders (Tuli and Bharadwaj, 2009). The study illustrates how the concept of sharing with customers as a part of marketing strategy maximises customer satisfaction. A successful marketing strategy and appropriate management of relationships ensures that customers are retained. For that it is important to focus on the concept of personalization in marketing that will drive the commitment value to the customer (Ashley et al., 2011). Commitment is termed as a natural ingredient in businesses for manufacturing a product as well as for a service rendered (Liu et al., 2011). Firms may take into account consumers' complains as well as suggestions and work towards them as part of their commitment towards customers. The basic rule for marketing a product is to provide the customers with the products and services best in the industry. This needs to be followed from the beginning to the end.
Assurance is considered as a great weapon for influencing a customer (Alqahtani, 2011). The best chances of customer retention are provided through practise of an exercise. Here the direct responses obtained through campaigns should be analysed and the suggestions should be carefully looked upon. Customer retention through after sales service earns goodwill for the company. This in turn will attract new customers. A good 'word of mouth' from the customer makes the firm more competitive and increases profit in the long run. A good customer relationship surely enhances the buyer-seller relationship. It also suffices within the customer a natural desire to receive things for the entire lifecycle apart from the core service or product. Consumers are known to derive satisfaction mainly because of good consumption experience or it may be some good after sales services (Theron and Terblanche, 2010). German consumers coming across borders to attend their accounts in Dutch bank can be cited as an example of effective customer relationship. Dutch companies are believed to be reliable, trustworthy and provide better investment opportunities. Through such foreign collaboration the consumer gets the assurance of a better financial deal (Nijsen and van Herk, 2009). Cross border engagement of the customers with the 
banks would help Dutch bank to develop a longstanding relationship with the customers. The customer loyalty here transforms into a motivation for maintaining a relation with the Foreign Service provider (Sichtmann and Selasinsky, 2010).

\section{MATERIALS AND METHODS}

Researchers have been conducted in the area of relationship marketing for getting ideas for customer satisfaction. Such researches have been reviewed as a part of this study. However, most theories of relationship marketing emphasize the role of trust and commitment in affecting performance outcomes. Relationship marketing generates short-term feelings of gratitude that has long-lasting benefits in terms of both performance and profits. Gratitude is the emotional component of human behavior that most firms may use to expand their business by preserving consumer's loyalty. A gratitude related behavior can be expected in return from the customer. Investment in relationship marketing generates customer value and creates more businesses. Aspects of relationship qualities including consumer trust and satisfaction have been highlighted here. They are positively related to the loyalty of the customer and contribute largely to the business growth Hence it is ideal for businesses to use a combination of both the aspects while adopting successful marketing strategies for customer satisfaction (Palmatier et al., 2009). Cross border shopping has emerged as a new challenge in the world of business and competition. Here customer satisfaction has emerged as an essential component for successful business in the context of world economy. It has already assumed double digit growth and is expected to grow more in the coming years (Nijssen and Herk, 2009). Such shopping involves a variety of products and services and is never confined to any specific product. All this have increased the need for preserving customer loyalty (Sichtmann and Selasinsky, 2010). Studies also show that the consumers do not want to participate in surveys or campaigns that are designed to measure the effects of relational marketing programs carried out by firms. They simply do not show any interests in these programs. In this environment of rivalry, businesses need to ensure that the customers are most interested in their product and not that of their rivals. Successful marketing strategies for customer retention involve creating a psychological attachment of the customer towards the firm's product. Appealing and convenient loyalty programs are now being undertaken by many firms so as to win consumer's confidence and preserve their loyalty (Ashley et al., 2011). Besides such psychological attachment bonding, relationship benefits, competence, alternative attractions, extension of customization and shared values are considered to be equally important for satisfying customers (Homburg et al., 2011). This factor contributes largely in maintenance of long term relationships with customers. Consumers' inclination towards a product depends positively on the dynamic relationship buyer and seller (Theron and Terblanche, 2010). Businesses in addition have to include the personalization effect in order to differentiate themselves from other potential rivals (Alvarez et al., 2010).

Relationship marketing: Retention of existing customers by strengthening relationships and preserving their loyalty is regarded as the essence of relationship marketing. It may also require serving the customer as a client. In some cases the situation may demand transformation of indifferent customers and winning their confidence. Marketing process considers acquiring new customer to be an intermediate step (Wagner et al., 2009). Lending support to customers even during closing hours develops within customers more respect for the organization (Palmatier et al., 2009). It also serves as an example of good salesmanship. Gratitude here is the key factor that enhances the quality of relation on one hand and obtains positive outcome for the seller on the other. Customers will never leave the organization if they are kept happy. This necessitates monitoring of some factors like availability of substitutes, customer satisfaction, trust and quality of services offered (Theron and Terblanche, 2010). Customers are found to be very particular about relationships. A careful study of past experiences, expectations and desires gives a good idea of consumer behaviour. Relationship Marketing simply does the job of collecting information based on which firms can identify their preferred customers and retain them. Relationship marketing is considered to be the tactic to achieve this. Many of the activities mentioned under the concept of relationship marketing are already being used by the firms. This increases customers' trust and satisfaction and in turn enhances profitability of the firm (Ashley et al., 2011).

The effects of relationship marketing on customer satisfaction: Relationship Marketing is chiefly concerned with building relationships at each and every possible point of interaction between the firms and the customers. This implies mutual benefit for the firms and the customers. Overall relationship marketing focuses on identifying factors affecting customer relationship with firms and works towards those factors 
in order to retain clients. In the field of stock markets more attention needs to be diverted towards the customers. Customer satisfaction plays a key role in influencing the risks on returns of a company's stocks (Sarlak and Fard, 2009; Jiang et al., 2009). Studies on this have suggested that there exists positive correlation between customer satisfaction and profitability baselines. This has also become the driving factor in the stock markets (Grewal et al., 2010). So before investing, evaluation of performance of the firms including the important criterion of customer satisfaction is equally important as that of returns on stocks. Else the investors might miss out some profit making opportunities (Tuli and Bharadwaj, 2009). A lot of research works have been undertaken to find out the impact of marketing actions on the level as well as heterogeneity of customer satisfaction. These aspects emerge as key factors in shaping up shareholder value (Grewal et al., 2010). Customer related outcomes obtained during short run affects a firm's performance in the long run (Tuli and Bharadwaj, 2009). Managers in recent times are assigned the task of striking a balance between customer retention policies and customer acquisition. This is done for tracing out the growth prospects of the firm (Grewal et al., 2010). Credibility of a firm in terms of performance and profitability in the eyes of stakeholders depends upon the entire performance of the mangers (Samaha et al., 2011). Customer relationship has now also emerged as a factor through which stakeholder's examine a firm in terms of profitability perspectives. Thus Relationship Marketing also brings in new investors for the firm.

Power or ability of the businesses to influence or control behaviour of the customers: Through past experiences and also through various reports and analysis the businesses intend to develop a firm idea about consumers' behaviour and their preferences and desires. The company seeks to increase sales and customer satisfaction by trying to build up a psychological attachment of the consumers towards the products. It also tries to manufacture products according to the consumer's likings and preferences. In this way the firm attempts to build up a bonding process. Such bonding processes in most cases have proved to be beneficial for both consumers and sellers.

Commitment towards customer: The firms try to maintain their commitment towards customers which in turn enhances customers' value and satisfaction. The customer also develops a desire for continuing with the firm. The firm proceeds in such a way so that customers pay regular visits and in turn become loyal to the firm's products. After sales services has emerged as an important tool in this respect.

Communication: Successful communication can play an important role in retaining old customers. It is mainly based upon the concept of sharing with customers. Through such formal and informal communications a firm tries to know more about consumer's preferences and also get to know if the customers have any complains or dissatisfaction.

Customization: The extension of customer services has proved to be an effective tool for customer retention. The seller in this case seeks information about the target buyers. After that the seller puts in lots of effort to cater to the needs of the buyer. The products as well as services are tailored in accordance with customer's preferences.

Gratitude: Through the social component of gratitude the customers develop more respect for the company and in turn become loyal to the company's products. Companies may try out after sales services or services during closing hours through which they expect a reciprocal behavior from customers. Such performance of seller helps in retaining customers. Gratitude is a very important instrument for preserving the loyalty of customers.

In customer retention strategies, switching costs are also to be kept in mind by the marketing strategist. This is nothing but the one-time costs the customers have to associate with given that they are switching from a specific provider to another. Such above mentioned dimensions would inject trust or willingness within the customer to rely on the service provider. All this will also help to restore the confidence of existing customers and bring in new customers. They are treated as pillar for successful customer relationship building.

\section{RESULTS AND DISCUSSION}

The development of reciprocal relationship between the customer and product is dependent on the responses of the customer. The behaviour and attitude of the consumer influences such relation. So trust and satisfaction should always be kept in mind when dealing with customers. Again personalization effect also helps in preserving loyalty of customers on which firms would concentrate. The firms should always try and produce goods and services according to the customer's preferences. Attempts should be made to grab customer's likings and make him psychologically attached to the company's products. Gratitude should 
always reflect in firm's performances. All this have been the essence of relationship marketing where customer satisfaction is given highest priority. So considering all this situations measures are to be taken so that more number of suspects becomes prospective buyers.

\section{CONCLUSION}

Relationship marketing as a pillar has not only given marketing a new dimension, but has also given more stress catering to the demand of customers for products and services. The industry's procedures to get desired outcomes and strategies adopted for increasing sales and customer satisfaction has been highlighted throughout the study. Several research works in this area have also been considered. Trust and satisfaction have been tagged as important for maintaining as wells enhancing a company's image. Along with relationship marketing antecedents, international marketing constructs are important for understanding consumer behaviour in cross-border settings. Factors such as commitment, customization, gratitude, communication took an important part of our study. Overall stress has been laid on the study of relationship marketing mainly to show how important it is to maintain healthy relation with customers in order to grow and acquire prosperity in businesses.

\section{REFERENCES}

Alqahtani, A.A., 2011. Toward a clarification of the concept of relationship marketing. Int. J. Manage.

Alvarez, L.S., R.V. Casielles and A.M.D. Martin, 2010. Analysis of the role of complaint management in the context of relationship marketing. J. Market. Manage., 27 : 143-164. DOI: $10.1080 / 02672571003719088$

Ashley, C., S.M. Noble, N. Donthu and K.N. Lemon, 2011. Why customers won't relate: Obstacles to relationship marketing engagement. J. Bus. Res., 64: 749-756. DOI: 10.1016/j.jbusres.2010.07.006

Grewal, R., M. Chandrashekharan and A.V. Citrin, 2010. Customer satisfaction heterogeneity and shareholder value. J. Market. Res., 47: 612-626. DOI: $10.1509 / \mathrm{jmkr} .47 .4 .612$
Homburg, C., M. Mullar and M. Klarmann, 2011. When should the customer really be king? on the optimum level of salesperson customer orientation in sales encounters. J. Market., 75: 55-74. DOI: 10.1509/jmkg.75.2.55

Liu, C.T., Y.M. Guo and C.H. Lee, 2011. The effects of relationship quality and switching barriers on customer loyalty. Int. J. Inform. Manage., 31: 7179. DOI: 10.1016/j.ijinfomgt.2010.05.008

Nijssen, E.J. and H.V. Herk, 2009. Conjoining international marketing and relationship marketing: Exploring consumers' cross-border service relationships. J. Int. Market., 17: 91-115.

Palmatier, R.W., C.B. Jarvis, J.R. Bechkoff and F.R. Kardes, 2009. The role of customer gratitude in relationship marketing. J. Market., 73: 1-18. DOI: 10.1509/jmkg.73.5.1

Samaha, S.A., R.W. Palmatier and R.P. Dant, 2011. Poisoning relationships: Perceived unfairness in channels of distribution. J. Market., 75: 99-117. DOI: $10.1509 / \mathrm{jmkg} .75 .3 .99$

Sarlak, M.A. and R.S. Fard, 2009. The impact of CRM on the customer satisfaction in agricultural bank. Am. J. Econ. Bus. Admin., 1: 167-172. DOI: 10.3844/ajebasp.2009.167.172

Sichtmann, C. and M.V. Selasinsky, 2010. Exporting services successfully: Antecedents and performance implications of customer relationships. J. Int. Market., 18: 86-108. DOI: 10.1509/jimk.18.1.86

Theron, E. and N.S. Terblanche, 2010. Dimensions of relationship marketing in business-to-business financial services. Int. J. Market Res., 52: 373-392. DOI: $10.2501 /$ S1470785309201326

Tuli, K.R. and S.G. Bharadwaj, 2009. Customer satisfaction and stock returns risk. J. Market.

Wagner, T., T. Hennig-Thurau and T. Rudolph, 2009. Does customer demotion jeopardize loyalty? J. Market., 73: 69-85. DOI: 10.1509/jmkg.73.3.69 